\title{
Short-Term Information Technology Training Impact on Research Self-Efficacy of Undergraduate Students at Provincial Cambodian Universities
}

\author{
Cheyvuth Seng \\ Department of Transdisciplinary Science and Engineering \\ School of Environment and Society \\ Tokyo Institute of Technology \\ Tokyo, Japan \\ Email: cheyvuth@yahoo.com \\ May Kristine Jonson Carlon \\ Department of Transdisciplinary Science and Engineering \\ School of Environment and Society \\ Tokyo Institute of Technology \\ Tokyo, Japan
}

Dr. Jeffrey S. Cross (Corresponding author)

Professor, Department of Transdisciplinary Science and Engineering

School of Environment and Society

Tokyo Institute of Technology

Tokyo, Japan

Email: cross.j.aa@m.titech.ac.jp

Received: January 9, 2020 Accepted: January 16, 2020 Published: February 25, 2020

doi:10.5296/ijld.v10i1.16206

URL: https://doi.org/10.5296/ijld.v10i1.16206 


\section{Macrothink}

\section{Abstract}

This paper aims to assess the effectiveness of research self-efficacy short-term information technology (IT) skills training intervention administered to $3^{\text {rd }}$ year and $4{ }^{\text {th }}$ year undergraduate students at three provincial Cambodian universities. The training intervention was conducted at the universities' computer centers where the internet could be accessed. The training lasted three weeks for 60 hours in total and covered topics such as using statistical analysis software, Massive Open Online Courses (MOOCs), and referencing software. The participants were 461 undergraduate students at universities during the 2018 academic year. The survey method used for this study was based on the "Research Self-Efficacy Scale" by Phillips and Russell (1994), which was administered before and after the training. The research used descriptive statistics and paired sample t-test for data analysis. The findings of the study revealed that the participants' research self-efficacy perceptions increased after conducting the intervention. The results showed that there was a significant increase in mean score after intervention based upon a 5-point scale from $2.10(\mathrm{SD}=0.68)$ before the intervention to $3.57(\mathrm{SD}=0.54)$ afterward. These findings suggest that IT training intervention is beneficial for undergraduate students at provincial universities in Cambodia resulting in an improvement in research self-efficacy.

Keywords: Research self-efficacy, self-efficacy, short-term intervention, undergraduate students, provincial universities, Cambodia

\section{Introduction}

Cambodia is one of the ten countries in the Association of Southeast Asian Nations (ASEAN), which consists of the other member states Vietnam, Thailand, Laos, Philippines, Singapore, Malaysia, Indonesia, Myanmar, and Brunei. The main task of ASEAN is to improve the stability of the region, is for member countries to collaborate actively and cooperate on issues of mutual concern in scientific and administrative fields within and outside the region (ASEAN, $2019 \mathrm{~b}$ ). To assist each other, through joint training and research activities covering educational, technical, administrative, and professional spheres (ASEAN, 2019a). Cambodia's total surface area is 181,035 square kilometers and is located next to its neighbors: Laos, Thailand, and Vietnam. Currently, Cambodia ranks seventieth and seventh in the ranking of countries by world population and in ASEAN, respectively, according to Countries in the world by population (2019). From 2008 to 2019, the total population of Cambodia rose from 13 million to 15 million, an increase of $14 \%$ in 11 years (Royal Government of Cambodia, 2019). Likewise, as claimed by the Cambodia Ministry of Education, Youth, and Sport (MoEYS), the students enrolled in the universities in 2018 reached 211,484, which is almost double the number compared with enrollment data in 2008 (Ministry of Education, Youth, and Sport [MoEYS], 2019).

\subsection{Research Capacity of Cambodian Higher Education}

The Cambodian higher education sector momentarily ceased operation during the civil war, which lasted from 1975 until 1979. The education system of Cambodia was re-established from 1979 to 1993, and postsecondary institutions started operating again (Sloper, 2000). In 
Cambodia, as reported by Hayden $(2019$, p. 20), "public universities have the necessary governance committee structures for the exercise of institutional autonomy, but their governing boards and academic committees have little or no decision-making authority." Despite having reopened several decades ago, according to Chen, Sok, \& Sok (2007), overall Cambodian higher education is still weak due to the lack of financial support, and the faculty do not have enough experience in teaching nor have they received adequate training. Hayden (2019) illustrates the challenges Cambodia, as well as Laos, face as they deal with insufficient reforms on the policy in their higher education systems and recommends that reforms be made based on a defined mission and vision.

According to Yun (2014), Cambodia's research culture in higher education is relatively weak compared with international standards. A recent study also reported that the Cambodian higher education is poorly developed when compared to several other Southeast Asian countries (Ngoy et al., 2019) due to the insufficiency of research infrastructure and inadequate funding support.

In today's fast-changing world, having the capacity to do research has become very important in meeting the demands of the globalized community, especially among educators. Nowadays, as universities are being significantly involved in knowledge transfer and innovation, they play an even more vital role in human capital development, as they are increasingly involved in knowledge transfer and innovation systems in their cities and regions (Brunner et al., 2012). A university's educational system needs research activity and research competency to understand the needs of their targeted market as well as to engage with international universities and their faculty. This is a problem for Cambodia; according to Yun (2014), even with the increase of foreign degree programs and foreign educational institutions, the movement of Cambodia's academic programs and providers are still underdeveloped. Apart from Laos and Myanmar the latter facing problems like Cambodia's - all ASEAN countries are far more developed than Cambodia (University World News, 2012). Developing higher education institution capabilities that also emphasize research publications in peer-reviewed journals has also been targeted by the World Bank in financing a 6-year grant from 2018-2024 for \$90 M (The World Bank 2020).

One key indicator to express the academic strength of any higher education institution is the academic and research qualifications/capabilities of their faculty members. Faculty members in Cambodian universities have low-quality research output as they are mostly involved in teaching since there is a financial incentive to teach compared to doing research. As a result, there are few opportunities for them to improve and no incentive to research due to limited funding. For instance, Chen et al. (2007) mentioned that $55 \%$ of the faculty member in Cambodia are full-time professionals; they spend most of their time teaching, so they do not get involved in research. Considering that academic competence is essential to the development of the country, it is easily understood that the human resources working in these institutions should be highly qualified. It is possible to realize the goals of the universities which function as motors in the development of our country in areas of social, cultural, research, economic, and technological fields by educating qualified instructors in research methodology. 


\subsection{Research Self-Efficacy and Interventions}

Students in higher education institutions are expected to actively use and apply knowledge obtained from various sources in every aspect of their lives by exercising critical thinking. Cambodian people generally place a higher value on the educational quality of overseas universities rather than their local universities, and one of the reasons is that education in developed countries focuses on research activity. This opinion has some precedent; a critical study by (Eam, 2015a) revealed that currently employed Cambodian university faculty members who graduated from overseas universities are continuing their research activity. This further reinforces the belief that those who graduated from programs in developed countries are more capable of understanding the way to conduct research and publish their results. It is found that the research knowledge of the students improves by taking more research-intensive courses (Rosenblatt \& Kirk, 1981). Nevertheless, undergraduate students' attitude towards their research competency may be negatively impacted by various reasons. One of the primary reasons is inadequate knowledge of research methodology.

Research self-efficacy may be described as confidence in one's ability to complete the end-to-end research process successfully (Kahn \& Scott, 1997). In general, Bandura defines self-efficacy as one's judgments about how well one can perform actions necessary to deal with several possible situations (Bandura, 1982, 1997). Waldman (2003) It is found that self-efficacy, positive attitude, and self-motivation greatly influence academic achievements. An empirical study showed that self-efficacy beliefs are directly useful in determining students' achievement and motivation levels (Chemers, Hu, \& Garcia, 2001). Studies demonstrated that research self-efficacy beliefs are crucial to evaluating the research productivity of graduate students and can be used to predict the research outcome expectation directly and indirectly (Bieschke et al. 1998; Phillips \& Russell, 1994).

Other studies have shown that to improve the research culture in Cambodia; self-efficacy interventions can be vital. After training, self-efficacy dramatically improved in the case of both men and women (Bakken et al., 2003). It is evident and is expected from the above results that more educational activities improve self-efficacy beliefs (Bandura, 1986). Interventions targeted at improving self-efficacy alone, even though not directly tackling the skill desired to be improved, can be a sufficient starting point for improvement. Multon et al. (1991) revealed in a study that self-efficacy interventions might boost interest and, ultimately, performance. Relich et al. (1986) revealed in their study that self-efficacy intervention functioned as a skill training and facilitated attributional feedback. The workshop intervention on research self-efficacy had a significant effect on increasing self-efficacy scores even before a short-term research training program was provided (Bakken et al., 2010).

On the topic of intervention research, there is a wide variety of techniques from clinical to administrative and from community organizations to policymaking, to name a few that can be used (Rothman, 1989). As more intervention research is being conducted, best or standard practices are being identified to guide future researchers, practitioners, and even policymakers. It was reported in the study of Bandura (1990) that awareness, modeling, rapid recovery, and social support are increased when informative dimensions are included in the intervention 
programs. Traditionally, the effectiveness of the intervention program has been assessed using time-specific comparisons of mean levels between the treatment group and the control groups (Curran \& Muthén, 1999).

\subsection{Tools for Research}

Some potential causes of negative attitudes towards research are the perceived difficulty in understanding the research-related fields such as statistics, insufficient skills in using software for data analysis and reference management, and lack of resourcefulness in finding relevant information to fill knowledge gaps that is research. The use of statistical software applications designed mainly for conducting statistical analysis is a crucial part of conducting statistical analysis (Abatan \& Olayemi, 2014; Chance et al., 2007). Statistical thinking includes the ability to summarize data, answer research questions, solve problems, understand the reasons behind underlying procedures, and make appropriate inferences from statistical analysis (Chance, 2002). De Leeuw (2011) mentioned that statistical software has become more and more critical in the last decade. Self-efficacy in using Statistical Package for Social Sciences (SPSS) ("IBM SPSS software," 2020), a statistical software, and attitudes towards computers were positive predictors of perceived usefulness among students who need to use statistical methodology to complete their work (Baglin, 2013). SPSS is beneficial for researchers in analyzing the results of research by conducting a variety of statistical analyses. According to Arkkelin (2014), within the academic and business circles, SPSS is a common choice for understanding and interpreting research results. Reflianto (2017) wrote that the use of software tools such as SPSS in training activities increased data processing capability in quantitative research activities.

Another essential skill for researchers that can be facilitated with software is reference management or recording and utilizing bibliographic information in research manuscripts. As mentioned by Basak (2015), researchers should use reference management tools in their research since this software typically performs essential functions such as transferring bibliographic entries from databases, creating personal databases, file management (e.g., searching through saved files), and even collaboration. Agrawal (2007) pointed out that the use of these software programs resulted in simplified reference management allowing the user to collect, store, and organize references, as well as insert citations appropriately within the content while writing a manuscript, and finally generate a list of references in an adequately formatted bibliographic style. Reference management software facilitates the research literature in an organized way since reference materials can be stored appropriately and tracked, aside from helping researchers know their relevant literature to facilitate future research (Jeyaprakash, 2015; Jeyaprakash et al., 2013).

Reference management software such as Mendeley ("Mendeley - Reference Management Software \& Researcher Network," 2020) are usually simple to install and are flexible - they can be used as word processor plugins, desktop applications, or through web browsers. Mendeley can generate a list of citations and bibliographies in most common document processing tools used by researchers such as Microsoft Word, OpenOffice, and LaTeX. Just like most reference management tools, Mendeley can store various citation styles in a Citation 
Style Language (CSL), which makes it easier for research manuscript writers to comply with various journals' author guidelines. According to Jeyaprakash (2015) said that Mendeley could support researchers in their work by providing a systematic and organized way of working with their references. It is a big help to researchers, users, and academicians (Parabhoi, 2017).

Throughout a research project, it is inevitable for researchers to find gaps in their knowledge that they must quickly fill. Massively open online courses (MOOCs), Tactics such as using social networking websites for teaching internet-based courses allow handling thousands of students simultaneously (Waldrop, 2013) provides the opportunity for university courses to be provided on a free or low-cost online platform. MOOCs require students to study video lectures, readings, assessments, and a variety of text-based or media resources and to finish assignments that are graded either by computers or by peers (Hollands \& Tirthali, 2014). A MOOC is typically defined as digitized materials offered freely or at low cost and openly as an educational resource for educators, students, and self-learners. They are usually reused for teaching, used for personal learning, and used as an aid for research (OECD, 2007). Gamage et al. (2016) concluded that the world is moving to many online learning technologies, and MOOCs are found to be one of the interventions which assist students in learning effectively and more collaboratively than the existing pedagogical models. Today, through MOOCs, many organizations around the world can reach hundreds of thousands or even millions of people. The combination of independent learning and accessibility that MOOCs provide can make it efficient for researchers to quickly gain the knowledge useful for their research at their own pace but still within a structured framework to help them assess if their learning has been enough.

\subsection{Purposes of the Present Study}

Since research self-efficacy is relevant in improving research activity along with the potential effectiveness of interventions, a short term intervention on IT use was created which aims to improve some selected practical research skills such as using SPSS software, Mendeley reference handling application and study of MOOCs (the students were required to enroll in a MOOC about methods for the training intervention). The purpose of this study is to investigate how Cambodia's undergraduate students at three provincial public universities rate the level of their research self-efficacy before and after this short-term intervention. We aim to answer the following research questions:

1- How do Cambodia's undergraduate students in provincial public universities perceive their research self-efficacy?

2- Will a short-term IT training intervention indirectly targeted at research self-efficacy positively affect their perceived research self-efficacy?

\section{Methodology}

Initially, the Cambodian MoEYS, which governs almost all the selected universities and the management of each university, was contacted requesting the universities participate in this study. For the second stage, the researcher additionally approached vital personnel of each university who was assigned by the university management to facilitate the researcher's data 
collection.

At the beginning of this study, during the pre-test, a total of 1,009 undergraduate students were selected among three public provincial universities. The names of the universities were undisclosed and re-named in alphabetical order as A, B, and $\mathrm{C}$. The pre-intervention questionnaire was collected from the selected participants who are undergraduate students in their third and fourth years between February and March during the 2018 academic year. The participants stated that they agree to participate voluntarily by completing the questionnaire forms. The participants were also requested to identify themselves and complete their necessary personal contact information (e.g., student name, telephone number, and e-mail address) for future training intervention and post-test.

The participants were adequately informed about the nature of the research, as well as their right to refuse to participate. Then the questionnaire was handed to them to answer. The participants were assured that their responses in the survey would remain confidential. All the participants were requested to fill out the demographic section of the questionnaire, which included gender, age, qualification, name of the university, and year. As all the survey participants were instructed to fill out each item as precisely as they could, incomplete forms were sorted out and discarded before data entry.

The intervention program was conducted from August to October in 2018 and consisted of three weeks at each of the universities. In order to conduct the research, the participant university was called by the researcher of the study and informed about the aims and conduct of the study. It is noted that students who did not participate in the pre-test survey were not considered in the analysis. Among 461 students, $65.7 \%$ of the students were third-year students, while $34.3 \%$ of those are in their fourth year. All students belonged to five different disciplines, such as Agriculture and Food Processing, Art, Humanities and Social Sciences, Business Administration and Tourism, Institute of Foreign Languages, and Science and Technology. Students who missed one or more weeks were also excluded from the sample for analysis.

In the study, the control group only completed the pre-test and post-test, and they continued to attend their classes at their university. The intervention group was told that they would participate in a three-week student activity program at the beginning of the study. The interventions were carried out for 60 hours over three weeks from Monday to Friday every morning from August to October 2018. The study was carried out on undergraduate students enrolled at provincial universities and trained by the researcher $(\mathrm{N}=461)$. Three universities' undergraduate students were assigned to each experimental classroom practice. All students were trained with three types of lessons, namely: SPSS, MOOCs, and Mendeley each week before the post-test and were informed in detail and in writing for each activity.

The post-tests were administered to the students approximately three weeks after the last intervention activity. The post-tests included the same questionnaire used during the pre-tests. The answers to the questions were rated by the respondents from 1 (strongly not confident) to 5 (strongly confident). All data from the pre- and post-test was analyzed using SPSS. Descriptive statistics (arithmetic mean and standard deviation) were used in describing data obtained from scale, and inferential statistics (paired sample t-test) was used to compare score change before 
the intervention and after the intervention. Table 1 shows the characteristics of the participants in the study in frequencies.

Table 1. Characteristics of participants in the study $(n=461)$

\begin{tabular}{lll}
\hline Variables & Levels/Items (Measurement) & $\boldsymbol{f ( \% )}$ \\
\hline Gender & $0=$ Male & $194(42.1)$ \\
1 & $=$ Female & $267(57.9)$ \\
Academic Year & $0=$ Year 4 & $158(34.3)$ \\
Faculty & $=$ Year 3 & $303(65.7)$ \\
1 & $=$ Science and Technology & $83(18)$ \\
2 & $=$ Business Administration and Tourism & $160(34.7)$ \\
3 & $=$ Agriculture and Food Processing & $102(22.1)$ \\
4 & $=$ Art, Humanities and Social Sciences & $82(17.8)$ \\
5 & $=$ Institute of Foreign Language & $34(7.4)$ \\
University & $=$ University A & $168(36.4)$ \\
2 & $=$ University B & $166(36.0)$ \\
3 & $=$ University C & $127(27.5)$ \\
\hline
\end{tabular}

\subsection{Instrument of Study}

As previously mentioned, the current study used a survey questionnaire method adapted from Philip and Russell (1994) for measuring research self-efficacy through the self-administered approach. The statistical population was the provincial Cambodia undergraduate students, with a sample size of 461 . These undergraduate students from three provincial public universities were gathered during their class time from their universities. They completed the questionnaires and expressed their opinions through these questionnaires, which were provided in hard copies.

The researcher has translated the original English text into the Cambodian language and rephrased some items to have sensible meaning in the Cambodian higher education context. A pilot test of the questionnaire was conducted on a small group of students before implementation. The original questionnaire contains 33- items and was measured by 0 - 9 Likert scale, with $0=$ no confidence to $9=$ total confidence. The words "dissertation" and "thesis" have the same meaning in the Cambodia language; hence the researcher has merged the items, "Writing the method and results sections of a dissertation" and "Writing the method 
and results sections of a thesis" as well as "Writing the introduction and literature review for a thesis" and "Writing the introduction and literature review for a dissertation," thus reducing to 31 - items. The scale was also modified to use " 1 = Strongly not Confident, 2 = Not Confident, 3 = Moderately Confident, 4 = Confident, and 5 = Strongly Confident” to avoid confusion.

\subsection{Training Intervention}

The undergraduate students were contacted by telephone numbers and e-mail addresses registered at their respective academic offices to invite them to attend the intervention for research self-efficacy to be conducted at their universities. The research self-efficacy training intervention was conducted at each university's computer centers where participants could have access to the internet. The participants in the intervention included the students who previously responded to the research self-efficacy survey. Again, we administered the same survey with the students after the training intervention.

\subsection{Data Analysis}

The data analysis was conducted using a statistical software program called SPSS. The analysis assessments, such as descriptive statistics and inferential statistics were performed to evaluate the patterns of students' level of research self-efficacy and to compare the mean differences of the research self-efficacy before and after the training intervention. The descriptive statistics allowed for interpretation of the statistical parameters, such as mean, standard deviation, and optimal values. The paired sample t-test of the inferential statistics was the statistical test used since we employed a repeated-measure design. We selected $p=0.05$ to be the level for judging if the result is statistically significant.

\section{Results}

The answers from the surveys were compared to analyze the research self-efficacy of the students before and after taking the training course. The collected data was likewise evaluated using the SPSS statistics program.

\subsection{Research Question 1: How do Cambodia's Undergraduate Students in Provincial Public Universities Perceive Their Research Self-Efficacy?}

The modified 31-item research self-efficacy questionnaire has Cronbach's alpha of 0.94. This correlation coefficient indicates that the reliability of our questionnaire is high. Table 2 compares the mean score per item before and after intervention research self-efficacy for the 461 participants from three public Cambodia provincial universities.

Before the intervention, the average level of confidence of undergraduate students ranged from the lowest scored skill "Writing the introduction and discussion sections for a research paper for publication" (total mean score of 1.74, SD of 0.81 ) to the highest scored skill "Keeping records during a research project" (total mean score of 2.69, SD of 1.00). After the intervention, the average level of confidence changed by ranging from the lowest "Writing the introduction and discussion sections for a research paper for publication" (total mean score of 3.19, SD of 0.92) and "Writing the method and results sections of a dissertation and thesis" (total mean score of 3.19, SD of 0.95) to the highest of "Selecting a suitable research topic for 
study" (total mean score of 4.19, SD of 0.81 ).

Table 2. Comparison of individual research self-efficacy mean scores before and after training intervention $(n=461)$.

\begin{tabular}{|c|c|c|c|c|c|c|c|}
\hline \multirow[b]{2}{*}{ Research Self-Efficacy } & \multicolumn{3}{|c|}{ Before intervention } & \multicolumn{3}{|c|}{ After intervention } & \multirow[b]{2}{*}{ Difference } \\
\hline & Mean & SD & $\begin{array}{l}\text { Minimum/ } \\
\text { Maximum }\end{array}$ & Mean & SD & $\begin{array}{l}\text { Minimum/ } \\
\text { Maximum }\end{array}$ & \\
\hline $\begin{array}{l}\text { Selecting a suitable } \\
\text { research topic for study }\end{array}$ & 2.49 & .90 & $1-5$ & 4.19 & .81 & $2-5$ & 1.70 \\
\hline $\begin{array}{l}\text { Designing an } \\
\text { experiment using } \\
\text { non-traditional methods } \\
\text { (e.g. ethnographic, } \\
\text { cybernetic, } \\
\text { phenomenological } \\
\text { approaches) }\end{array}$ & 2.04 & .79 & $1-5$ & 3.74 & .83 & $2-5$ & 1.70 \\
\hline $\begin{array}{l}\text { Designing an } \\
\text { experiment plan using } \\
\text { traditional methods (e.g. } \\
\text { experimental, } \\
\text { quasi-experimental } \\
\text { designs) }\end{array}$ & 2.05 & .85 & $1-5$ & 3.66 & .83 & $2-5$ & 1.61 \\
\hline $\begin{array}{l}\text { Controlling variables } \\
\text { that impact the validity } \\
\text { of research results }\end{array}$ & 2.21 & .90 & $1-5$ & 3.69 & .88 & $2-5$ & 1.47 \\
\hline $\begin{array}{l}\text { Formulating scientific } \\
\text { hypotheses }\end{array}$ & 2.04 & .89 & $1-5$ & 3.66 & .88 & $1-5$ & 1.62 \\
\hline $\begin{array}{l}\text { Selecting a sample of } \\
\text { subjects from a given } \\
\text { population (statistical } \\
\text { analysis) }\end{array}$ & 2.17 & .88 & $1-5$ & 3.72 & .95 & $1-5$ & 1.55 \\
\hline
\end{tabular}


Before intervention

Research Self-Efficacy
Mean SD Minimum/

Maximum
After intervention

Mean SD Minimum/

Maximum

Difference

\begin{tabular}{llllllll} 
& & \multicolumn{3}{c}{ Maximum } & \multicolumn{3}{c}{ Maximum } \\
\hline $\begin{array}{l}\text { Selecting reliable and } \\
\text { valid instruments }\end{array}$ & 1.94 & .89 & $1-5$ & 3.64 & .90 & $2-5$ & 1.70
\end{tabular}

valid instruments

Operationalizing

variables of interest

Finding enough

research participants

Keeping records during

a research project

Collecting data

Making time for

research

Contacting researchers

currently working in an

area of research interest

Finding and using

resources when needed

Defending a thesis or

dissertation

Getting money or

funding to help pay for

research

Knowing which statistics test to use

$2.24 \quad .92 \quad 1-5$

3.64

$.93 \quad 2-5$

$2.36 \quad .90 \quad 1-5$

$3.76 \quad .90 \quad 2-5$

$\begin{array}{ll}2.69 & 1.0 \\ 0 & 1-5\end{array}$

$3.77 \quad 90 \quad 2-5$

1.08

$2.50 \quad .97 \quad 1-5$

$3.73 \quad .91 \quad 2-5$

$2.68 \quad .99 \quad 1-5$

$3.74 \quad 96 \quad 2-5$

1.06

$2.39 \quad .92 \quad 1-5$

$3.77 \quad .91 \quad 1-5$

1.38

$2.52 \quad .97 \quad 1-5$

$3.73 .91 \quad 2-5$

$2.17 \quad .97 \quad 1-5$

$3.56 \quad .86 \quad 2-5$

$2.17 \quad .99 \quad 1-5$

$3.50 \quad .97 \quad 2-5$
$1.98 \quad .84 \quad 1-5$

$3.56 \quad .90 \quad 2-5$

1.57 
Before intervention

Research Self-Efficacy
After intervention

Mean SD Minimum/

Mean SD Minimum/

Difference

Maximum

Maximum

$1.98 \quad .92 \quad 1-$

3.58

$.93 \quad 1-5$

1.60

input it in a computer

system

Avoiding the violation

1.94

.89

$1-5$

3.50

$.90 \quad 1-5$

1.56

of statistical

assumptions

Using simple statistics

$2.07 \quad .86 \quad 1-5$

$3.62 \quad .95 \quad 1-5$

1.55

(e.g., t-test, ANOVA,

correlation, etc.)

Understanding

$2.09 \quad .94 \quad 1-5$

3.62

$.93 \quad 1-5$

1.54

computer printouts

Using multivariate

$1.80 \quad .79 \quad 1-5$

$3.39 \quad .89 \quad 1-5$

statistics (e.g., multiple

regression, factor

analysis, etc.)

Using statistical

$\begin{array}{lll}1.87 & .85 & 1-4\end{array}$

$3.39 \quad .99 \quad 1-5$

software packages (e.g.,

SPSS-X, SAS, etc.)

Writing statistical

$1.85 \quad .85 \quad 1-5$

$3.37 \quad .99 \quad 1-5$

1.52

computer programs

Writing a paper for a

$1.87 \quad .84 \quad 1-5$

$3.37 \quad .98 \quad 1-5$

1.50

conference proceeding

Writing the method and

$1.83 \quad .84 \quad 1-5$

$3.28 \quad .90 \quad 1-5$

1.45

results section for a

research paper for

publication 


\section{Before intervention After intervention}

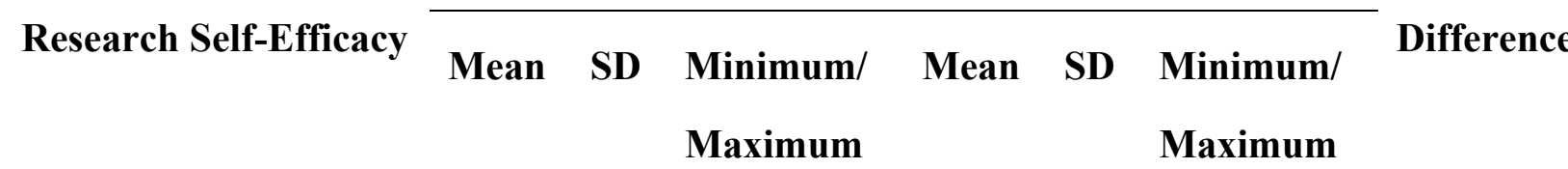

Writing a discussion

$\begin{array}{lll}1.84 & .87 \quad 1-5\end{array}$

3.36

$.93 \quad 1-5$

1.52

section for a thesis or

dissertation

Writing the introduction

$1.85 \quad .85 \quad 1-4$

$3.26 \quad .95 \quad 1-5$

and literature review for

a thesis

Reviewing the literature

$2.02 \quad .87 \quad 1-5$

3.43

$1.0 \quad 1-5$

in an area of research

interest

Writing the introduction

$1.74 \quad .81 \quad 1-5$

3.19

$.92 \quad 1-5$

1.45

and discussion sections

for a research paper for

publication

Writing the method and

$\begin{array}{lll}1.82 & .85 & 1-4\end{array}$

3.19

$.95 \quad 1-5$

1.37

results sections of a

dissertation and thesis

\subsection{Research Question 2: Will a Short-Term Training Intervention Indirectly Targeted at} Research Self-Efficacy Positively Affect Their Perceived Research Self-Efficacy?

As can be seen from the results of the analysis in Table 3, which shows the respondents' research self-efficacy before and after the training intervention, the mean scores of research self-efficacy show a significant difference with p-value .001 , ( $[460]=36.27, \mathrm{p}<.000)$. The mean scores of research self-efficacy after the intervention (total mean score of 3.57, SD total mean score of 0.54 ) were higher than the before intervention scores (total mean score of 2.10, $\mathrm{SD}$ of 0.68 ). It was seen that the average score of the research self-efficacy results show a significant difference, which means that the two measures were significantly different (total mean score of 1.47). The difference showed that after the training intervention, the students' performance in research self-efficacy improved. 
Table 3. Undergraduate student's research self-efficacy score before and after the intervention $(\mathrm{n}=461)$.

\begin{tabular}{lllllll} 
& \multicolumn{2}{c}{ Before intervention } & \multicolumn{2}{c}{ After intervention } & \multicolumn{2}{c}{ Paired samples test } \\
\cline { 2 - 7 } Component & Mean & SD & Mean & SD & t & P \\
\hline Research Self-Efficacy & 2.10 & 0.68 & 3.57 & 0.54 & 36.27 & .000 \\
\hline
\end{tabular}

Note. $\mathrm{SD}=$ Standard Deviation; $*=\mathrm{p}$-value $<0.05 ; * *=\mathrm{p}$-value $<0.01 ; * * *=\mathrm{p}$-value $<0.001$

\section{Discussion}

In this study, the evaluation of the effectiveness of research self-efficacy training intervention for undergraduate students at provincial universities in Cambodia was discussed. A separate study has previously shown that the research self-efficacy of undergraduate students in provincial universities in Cambodia was low (Seng et al., 2019b). The results of this current study indicate that for most undergraduates, participation in the intervention was effective, at least in the short term. The mean scores of research self-efficacy increased after the training was conducted. This finding is parallel to the one obtained by Seng et al. (2019a), where a similar trend in information literacy self-efficacy was found on the same population using similar techniques (i.e., conducting training that can contribute to the target behavior but not directly relating to it). Our choice for the evaluation of our training program (Research Self-Efficacy Scale by Phillip and Russell) is similar to the study of Becher Al-Halabi et al. (2014) revealed that the research self-efficacy mean score of the undergraduate students on the same measurement tool showed a significant improvement after conducting their study.

Other similar findings from Al-Tannir et al. (2018) also showed that training programs result in a marked increase in research knowledge and skills of the participants who were medical students. In the study of Reflianto (2017), the participants exhibited significant improvements after the training program on processing quantitative research data. Workshops that teach how to acquire knowledge from prior studies have been shown to improve basic research knowledge (Abdulghani et al., 2014; Mullan et al., 2014). Thus, these results showing that research self-efficacy increased after training was conducted is not entirely new. The contribution of this research to the field is that using a training program that did not directly address research self-efficacy itself can have an impact on a population whose research competencies are rarely studied.

A research training course has been proven to be an essential item to develop excellent research skills (Becher Al-Halabi et al., 2014). However, for undergraduate students at provincial research universities in Cambodia, where most universities follow the teaching-oriented university system, the research method is only a single course in the entire curriculum offered during their fourth year. This usually comprises of just 45 hours of instruction without actual research practice. This is the situation for all the universities we selected for this research (Note 
1). This phenomenon is not surprising; Eam (2015a) argued that the overall level of research activities in Cambodia ranked very low in terms of research at the university level when compared to international standards. Even the faculty members working in provincial universities alarmingly undertake little research work (Eam, 2015a).

In the research work of Nagda et al. (1998), it is noted that the students who are involved in research work with a faculty member show more research persistence. Hence, if direct instruction in research is not an option, then learning by doing can be an option for students to develop their research skills. However, as previously mentioned, most of the Cambodian faculty were inactive in research production activities and research involvement; thus, the opportunity for hands-on learning is also not available to most Cambodian students. Not even research experience before joining the faculty ranks can speak for most of the Cambodian faculty: it was noted that only 6 percent of the lecturers at Cambodian universities hold a Ph.D. degree, and 90 percent have not published a journal paper (Chen et al., 2007). A later study by Eam (2017) also showed that Cambodian faculty members were less active in their research, which made their research productivities limited. Even in the rare case, when a student gets exceptionally interested in research to initiate research activities on their own without any support from faculty, the students may still face insurmountable challenges. In most of the Cambodian libraries, books and other study resources are old and inadequate compared to their demand. More than that, research facilities and infrastructures are not sufficient to serve for research activities.

Ideally, students should have opportunities to apply their knowledge and skills achieved in undergraduate studies to undertake some, although limited research activity related to their coursework. For instance, undergraduate research is a valued co-curricular activity that has involved an increasing number of students and faculty members in recent years (Webber et al., 2013). The National Leadership Council for Liberal Education and America's Promise (2007) suggested that research activities should be integrated into the curriculum even though it may affect retention and graduation rates. Research-based education is an essential part of social-scientific study programs because students are exposed to research methods in early stages, thus acquiring hands-on experiences in research projects and can demonstrate research competency when working towards their final theses (McKinney et al., 2004).

\section{Implications for Research Development}

There are several implications for MoEYS, research policymakers, and other stakeholders from this research. As per Eam (2015b), if Cambodia wants to ensure the alleviation of its research culture, it must have a clear vision and direction for their research and development activities. Leckey and Neill (2001) shared that universities have to ensure a standard curriculum that could create a program auditing committee that will encompass peer evaluation among teachers and receive course evaluations from the students.

Provincial universities in Cambodia should consider integrating research into their curriculum from the first year until the fourth year. The curriculum could include various activities such as actual research experience, instruction aimed at developing research skills, surveying research interest, and enhancing research motivation among undergraduate students, in the Khmer 
language. Higher education must aim for improving research competency (Gess et al., 2018). Neumann (1994) found that having research experience leads to positive benefits for the students, including better perceptions of course credibility, relevance, and timeliness. A shift from teaching-orientation to research-orientation, and resources being allocated from just for city-based universities to provincial universities as well, could help revolutionize the way Cambodians view the importance of increasing research competencies of both the educators and the students to address the needs and demands of building a stronger Cambodian society. Abdulghani et al. (2014) identified research culture and work-based learning as the most influencing factors on research promotion.

According to research on Cambodian faculty's research intention conducted by Eam and Seng (2017), the level of wanting to undertake research may define the relationship between skills and knowledge of research and level of the intention of an individual to deal with future research activities. Thus, first and foremost, the faculty should be encouraged to increase their research participation. Kuh et al. (2007) discovered that the importance that faculty members place on undergraduate research is positively related to the proportion of students participating in undergraduate research. Likewise, Lamanauskas and Augienè (2014) found that a lecturer's experience and attention is given to a student's scientific activity often has a decisive influence on the student's research experience. In the event of less than desirable outcomes, Massy (2003) said that new ideas to improve quality education might be generated when the faculty members practice sharing their experiences

Aside from bolstering faculty involvement, universities can also consider integrating computer information technology such as data analytics software like SPSS, MOOCs, and reference management software like Mendeley to give more research activity exposure to their students. Universities are ideally able to give training related to scientific writing, statistics, and research methods because these provide inspiration and knowledge to students, which facilitate their research skills development (Yulianto, 2017). These trainings can significantly improve students' research skills and increase their confidence in writing their bachelor thesis in order to fulfill their graduation requirements. With IT research technology-related training, students may be able to understand better essential aspects of research, such as data analysis and literature review using tools. Research-based learning is vital in the undergraduate curriculum (Turner et al., 2008). A critical component in research is in creating new knowledge and applying obtained knowledge in a very creative way (Sachitra, 2016).

The importance of hands-on experiences in research cannot be overstated. According to Bandura (1997), the most potent source of self-efficacy beliefs is the direct experiences of individuals. For instance, Mullan et al. (2014) said that medical students' participation in research projects provided them with opportunities to develop and improve their research capacities as future medical practitioners.

As an example, in an undergraduate setting, third-year undergraduate students at Tokyo Institute of Technology are required to visit Professor's laboratories within their departments to learn about research activities in faculties lab that may interest them the most and select a lab to conduct their fourth-year research project (Tokyo Institute Technology, 2018) which is 
required for graduation. Undergraduate students who experience doing research learn to balance collaborative and individual work, determine an area of interest, and are bound to start their future careers (Madan \& Teitge, 2013). The increase in more postgraduate researchers and their future achievements in research work is strongly correlated with the research experience of the students throughout the college years (Becher Al-Halabi et al., 2014).

Aside from curriculum and faculty development, as per Chen et al. (2007), developing course materials and facilities play a vital role in promoting research work where the government and the universities should focus more. Funding for scientific research, engagement of skilled research personnel, and communication of research outputs and specific scientific information for policymaking are just some of the challenges confronting developing countries (Sanni et al., 2016). It was noted by Chen et al. (2007) found that Cambodia is spending very little on journals and periodicals subscription, new textbooks procurement, facilities modernization, and other activities related to conducting research.

As noted above, the World Bank has expressed the intention to support research activities in Cambodia (The World Bank, 2020). However, these funds are usually only accessible to individuals or institutions who have previously demonstrated the capacity to do research. One option for teaching-oriented faculty members to polish their research credentials is to allocate part of their teaching time to conducting research related to their subject with their students. This has the additional benefit of developing the students' research self-efficacy as well. However, this is only possible if the faculty members have enough research capabilities to begin with, which we had previously pointed out, is not a typical case. Thus, it is still beneficial for the Cambodian government to consider increasing budget education for public universities located in the provinces. For instance, in 2012, the government had spent only $0.1 \%$ of the country's GDP or $4.1 \%$ of the MoEYS budget for higher education in Cambodia, as reported by Un and Sok (2014).

For Cambodia, which has a third-world economy, it is logical to consider that the government should provide financial support for higher education institutions that are researching for the benefit of society. Even if there is the political will to support research, providing research funding may be difficult for the Cambodian government given budget restrictions. However, there are other options, such as provincial universities encouraging faculty members with research expertise to form and lead research groups that will provide research mentorship for junior faculty members. This could gradually improve the faculty members' research output, which can, in turn, make them more competitive in participating in future externally funding projects with overseas institutions. Provincial universities need to consider acquiring adequate funds to support educational research activities, implement goals and strategies, renew facilities and provide financial aid in order to promote research in undergraduate education (Chickering \& Gamson, 1987).

Initiatives such as workshops on research can positively influence participants' general practices and knowledge of research (Ried et al., 2008). Moreover, the university can form research groups and then involve the students in these groups if they are interested in research activity. However, the research theme may not be directly related to their research interest 
(Galeano et al., 2012).

\section{Conclusion}

In this study, we concluded that short-term IT intervention on Cambodian undergraduate students in three public provincial universities has been effective since the mean research self-efficacy scores increased. We observed that research self-efficacy scores differ pointedly before and after the IT training intervention. The results of the present research affirm the beneficial role of training interventions increased research self-efficacy, which can lead to enhanced research knowledge and skills in general. Based on these results, there is a need to implement similar trainings in other provincial universities in Cambodia, especially in aspects related to the students' major and allow them to demonstrate their knowledge. MoEYS should develop policies based on the findings in this study to reform its curricular decision-making by designing and implementing long term research programs for the undergraduate level. Although this research was conducted in Cambodia, we feel that these findings are transferrable to other developing countries based on the reviewed literature.

\section{Limitations and Future Research}

Since the scope of this research focused on only the quantitative method approach, further study using the qualitative method approach is suggested to advance the research self-efficacy evaluation. This further study should include observation, interview, group discussions, case study analysis, and longitudinal studies. Qualitative method approaches can provide more abundant information as to what challenges students, and the faculty are experiencing concerning research production and promotion.

Moreover, it is also suggested that the IT training program should be made available for faculty members within the scope of their teaching and mentoring practices. As previously mentioned, the faculty attitude and skill are strong determinants for students' success in research; thus, we believe it is worthwhile to invest in the faculty's professional development as well.

Finally, it is essential to know if the intervention has long term effects. A follow-up investigation was conducted in January 2020 with selected students to access their knowledge after the intervention. Analysis of this data is on-going and will be reported in the future. Also, since the intervention supposedly increased research self-efficacy, it is valuable to check if students who received the training are more dispositioned to improve their research skills than those who were not able to receive the same opportunity.

\section{Acknowledgements}

The authors sincerely appreciate the support and scholarship provided by JICA (Japan International Cooperation Agency) to the first author.

\section{References}

Abatan, S. M., \& Olayemi, M. (2014). The role of statistical software in data analysis. International Journal of Applied Research and Studies (IJARS) ISSN, 2278-9480. Retrieved from https://ssrn.com/abstract=2532326 
Abdulghani, H. M., Shaik, S. A., Khamis, N., Al-Drees, A. A., Irshad, M., Khalil, M. S., ... Isnani, A. (2014). Research methodology workshops evaluation using the Kirkpatrick's model: Translating theory into practice. Medical Teacher, 36(1), S24-S29. https://doi.org/10.3109/0142159X.2014.886012

Agrawal, A. (2007). EndNote 1-2-3 Easy!: Reference Management for the Professional. Springer Science \& Business Media. https://doi.org/10.1007/978-0-387-95901-6

Al-Tannir, M., Abu-Shaheen, A., AlSumaih, S., AlMukaibil, N. F., AlHarbi, R., Heena, H., ... AlFayyad, I. (2018). Research knowledge and skills among medical and allied health students attending a summer research course: A pretest and posttest analysis. Cureus, 10(8). https://doi.org/10.7759/cureus.3132

Aldridge, S., \& Rowley, J. (1998). Measuring customer satisfaction in higher education. Quality Assurance in Education, 6(4), 197-204. https://doi.org/10.1108/09684889810242182

Arkkelin, D. (2014). Using SPSS to understand research and data analysis. Psychology Curricular Materials Book 1. Retrieved from http://scholar.valpo.edu/psych_oer/1

ASEAN. (2019a). About ASEAN. Retrieved from https://asean.org/asean/about-asean/

ASEAN. (2019b). Invest in ASEAN. Retrieved from http://investasean.asean.org/index.php/page/view/aseanmemberstates/view/709/newsid/794/c ambodia.html

National Leadership Council for Liberal Education and America's Promise. (2007). College learning for the new global century. Washington, DC: Association of American Colleges and Universities.

Retrieved

from https://www.aacu.org/sites/default/files/files/LEAP/GlobalCentury_final.pdf

Baglin, J. (2013). Applying a theoretical model for explaining the development of technological skills in statistics education. Technology Innovations in Statistics Education, $7(2), 1-17$.

Bakken, L. L., Byars-Winston, A., Gundermann, D. M., Ward, E. C., Slattery, A., King, A., ... Taylor, R. E. (2010). Effects of an educational intervention on female biomedical scientists' research self-efficacy. Advances in Health Sciences Education, 15(2), 167-183. https://doi.org/10.1007/s10459-009-9190-2

Bakken, L. L., Sheridan, J., \& Carnes, M. (2003). Gender differences among physician-scientists in self-assessed abilities to perform clinical research. Academic Medicine, 78(12), 1281-1286. https://doi.org/10.1097/00001888-200312000-00018

Bandura, A. (1982). Self-efficacy mechanism human agency. American Psychologist, 37(2), 122-147. https://doi.org/10.1037/0003-066X.37.2.122

Bandura, A. (1986). Social foundations of thought and action: A social cognitive theory. The Englewood Cliffs, NJ: Prentice-Hall.

Bandura, A. (1990). Perceived self-efficacy in the exercise of control over AIDS infection. 
Evaluation

and

Program

Planning,

$13(1)$

$9-17$.

https://doi.org/10.1016/0149-7189(90)90004-G

Bandura, A. (1997). Self-efficacy: The exercise of control. Freeman, New York.

Basak, S. (2015). A comparison of three reference management software: Jabref, Zotero, and Endnote. International Journal of Research in Information Technology, 3(4), 223-231.

Becher Al-Halabi, Y. M., Hasan, M., \& Alkhadhari, S. (2014). Extracurricular research activities among senior medical students in Kuwait: Experiences, attitudes, and barriers. Advances in Medical Education and Practice, 5, 95-101. https://doi.org/10.2147/amep.s61413

Bieschke, K. J., Herbert, J. T., \& Bard, C. (1998). Using a social cognitive model to explain research productivity among rehabilitation counselor education faculty. Rehabilitation Education, 12, 1-16.

Brunner, J. J., Gacel-Avilà, J., Laverde, M., Puukka, J., Rubio, J., Schwartzman, S., \& Valiente, Ó. (2012). Higher education in regional and city development: Antioquia, Colombia 2012. Paris: OECD Publishing.

Chance, B., Ben-Zvi, D., Garfield, J., \& Medina, E. (2007). The role of technology in improving student learning of statistics. Technology Innovations in Statistics Education Journal, 1(1).

Chance, B. L. (2002). Components of statistical thinking and implications for instruction and $\begin{array}{llll}\text { assessment. Journal of Statistics } & \text { Education, }\end{array}$ https://doi.org/10.1080/10691898.2002.11910677

Chemers, M. M., Hu, L. T., \& Garcia, B. F. (2001). Academic self-efficacy and first-year college student performance and adjustment. Journal of Educational Psychology, 93(1), 55-64. https://doi.org/10.1037/0022-0663.93.1.55

Chen, C. Y., Sok, P., \& Sok, K. (2007). Benchmarking potential factors leading to education quality: A study of Cambodian higher education. Quality Assurance in Education, 15(2), 128-148. https://doi.org/10.1108/09684880710748901

Chickering, A. W., \& Gamson, Z. F. (1987). Seven principles for good practice in undergraduate education. AAHE Bulletin, 39, 3-7.

Countries in the world by population. (2019). Cambodia Population (2019) - Worldometers. Retrieved from http://www.worldometers.info/world-population/population-by-country/

Curran, P. J., \& Muthén, B. O. (1999). The application of latent curve analysis to testing developmental theories in intervention research. American Journal of Community Psychology, 27(4), 567-595. https://doi.org/10.1023/A:1022137429115

De Leeuw, J. (2011). Statistical software: An overview. International Encyclopedia of Statistical Science, 1470-1473. https://doi.org/10.1007/978-3-642-04898-2_553 
Eam, P. (2015a). Faculty involvement in research activities at Cambodian public higher education institutions: Trends, patterns and key characteristics. International Journal of Comparative Education and Development, 17(2), 97-114.

Eam, P. (2015b). Investigating relationship among research self-efficacy, research outcome expectation, and research interest of Cambodian faculty: Testing social-cognitive theory. International Journal of Sociology of Education. 4(3), 199-224. https://doi.org/10.17583/rise.2015.1752

Eam, P. (2017). A study on the research ability and mindset of Cambodian faculty members and their research outputs: A perspective from fifteen higher education institutions (Doctoral dissertation, 広 島 大 学 (Hiroshima University)). Retrieved from https://ir.lib.hiroshima-u.ac.jp/en/00043691

Eam, P., \& Seng, C. (2017). A path analysis of Cambodian faculty's research intention: Focusing on direct and mediating effects at individual level. International Journal of Sociology of Education, 6(3), 271-295. https://doi.org/10.17583/rise.2017.2777

Galeano, N., Morales-Menendez, R., \& Cantú, F. J. (2012). Developing research skills in undergraduate students through an internship program in research and innovation. International Journal of Engineering Education, 28(1), 48-56.

Gamage, D., Perera, I., \& Fernando, S. (2016). Improving effectiveness of MOOCs. Copyright 2016 Asia-Pacific Society for Computers in Education All rights reserved. No part of this book may be reproduced, stored in a retrieval system, transmitted, in any forms or any means, without the prior permission of the Asia-Pacific Society for Computers in Education.

Gess, C., Geiger, C., \& Ziegler, M. (2018). Social-scientific research competency: Validation of test score interpretations for evaluative purposes in higher education. European Journal of Psychological Assessment, 35(5), 737-750. https://doi.org/10.1027/1015-5759/a000451

Hayden, M. (2019). Challenges to higher education in Laos and Cambodia. International Higher Education, (97), 20-21. https://doi.org/10.6017/ihe.2019.97.10947

Hollands, F., \& Tirthali, D. (2014). MOOCs: Expectations and reality. Full report. Center for Benefit-Cost Studies of Education, Teachers College, Columbia University, NY. Retrieved from https://files.eric.ed.gov/fulltext/ED547237.pdf

$\begin{array}{llll}\text { IBM } & \text { SPSS } & \text { (2020). } & \text { Retrieved }\end{array}$ https://www.ibm.com/analytics/spss-statistics-Software

Isak, Y. M., \& Sokang, Y. A. (2017). Research self-efficacy: Bachelor student \& the thesis. In 2017 International Multidisciplinary Conferences on Productivity and Sustainability Jakarta, 5-7 December 2017 (pp. 117-120). Retrieved from http://imps2017.ukrida.ac.id/repository/proceeding/Isak_and_Sokang_(2018).pdf

Jeyaprakash, B. (2015). Reference management tools for effective research: With special reference to MENDELEY. International Journal of Science and Humanities, 1, 387-396. 
Jeyaprakash, B., Geetha, V., \& Prabhu, R. (2013). Open source reference management tools: A special reference to MENDELEY. Retrieved from http://14.139.186.108/jspui/bitstream/123456789/6116/1/open\%20source\%20reference\%20m anagement.pdf

Kahn, J. H., \& Scott, N. A. (1997). Predictor of research productivity and science-related career goals among counseling psychology doctoral students. The Counseling Psychologist, 25(1), 38-67. https://doi.org/10.1177/0011000097251005

Kuh, G., Chen, D., \& Laird, T. F. N. (2007). Why teacher scholars matter: Some insights from NSSE and FSSE. Liberal Education, 93(4), 40-45.

Lamanauskas, V., \& Augienè, D. (2014). Bachelor students' scientific research activity at university: Situation analysis and improvement possibilities. In Science and technology education for the 21st century: Research and research-oriented studies (Proceedings of the $9^{\text {th }}$ IOSTE symposium for Central and Eastern Europe). Hradec Kralove: Gaudeamus Publishing House (pp. 297-312).

Leckey, J., \& Neill, N. (2001). Quantifying quality: The importance of student feedback. Quality in Higher Education, 7(1), 19-32. https://doi.org/10.1080/13538320120045058

Madan, C. R., \& Teitge, B. D. (2013). The benefits of undergraduate research: The student's perspective. The Mentor: Innovative Scholarship on Academic Advising, 15. https://doi.org/ 10.26209/MJ1561274

Massy, W. F. (2003). Auditing higher education to improve quality. The Chronicle Review, 49(41), 16.

McKinney, K., Howery, C. B., Strand, K. J., Kain, E. L., \& Berheide, C. W. (2004). Liberal learning and the sociology major updated: Meeting the challenge of teaching sociology in the twenty-first century. Washington, DC: American Sociological Association. Retrieved fromhttps://www.asanet.org/sites/default/files/savvy/documents/teaching/pdfs/Lib_Learning_ FINAL.pdf

Mendeley - Reference Management Software \& Researcher Network. (2020). Retrieved from https://www.mendeley.com/?interaction_required=true

Ministry of Education, Youth and Sport [MoEYS]. (2019). Education strategic plan 2019-2023. Phnom Penh: MoEYS Publication. Retrieved from https://www.globalpartnership.org/sites/default/files/2019-10-education_sector_plan-cambodi a.pdf

Mullan, J. R., Weston, K. M., Rich, W. C., \& McLennan, P. L. (2014). Investigating the impact of a research-based integrated curriculum on self-perceived research experiences of medical students in community placements: A pre- and post-test analysis of three student cohorts. BMC Medical Education, 14(1), 1-9. https://doi.org/10.1186/1472-6920-14-161

Multon, K. D., Brown, S. D., \& Lent, R. W. (1991). Relation of self-efficacy beliefs to academic outcomes: A meta-analytic investigation, Journal of counseling psychology, 38(1), 
30-38. https://doi.org/10.1037/0022-0167.38.1.30

Nagda, B. A., Gregerman, S. R., Jonides, J., Hippel, W., \& Lerner, J. S. (1998). Undergraduate student faculty research partnerships affect student retention. Review of Higher Education, 22(1), 55-72. https://doi.org/10.1353/rhe.1998.0016

Neumann, R. (1994). The teaching-research nexus: Applying a framework to university students' learning experiences. European Journal of Education, 29(3), 323-338. https://doi.org/10.2307/1503744

Ngoy, M., Say, S., \& Leang, U. (2019). Governance in public higher education in Cambodia. CDRI Working Paper Series No. 114. Phnom Penh: CDRI.

OECD. (2007). Giving knowledge for free: The emergence of open educational resources. Retrieved from http://www.oecd.org/education/ceri/38654317.pdf

Parabhoi, L. (2017). How Mendeley helps to your research work? In National Conference of Agricultural Libraries \& User Community (NCALUC-2017) on Libraries Beyond Borders: Navigating Towards Global Dissemination (pp. 64-70).

Phillips, J. C., \& Russell, R. K. (1994). Research self-efficacy, the research training environment, and research productivity among graduate student in counseling psychology. The Counseling Psychologist, 22(4), 628-641. https://doi.org/10.1177/0011000094224008

Reflianto, R. (2017). Improvement of students' ability on statistical software application (public service on Islamic student for early childhood education program). In International Conference of Early Childhood Education (ICECE 2017). Atlantis Press.

Relich, J. D., Debus, R. L., \& Walker, R. (1986). The mediating role of attribution and self-efficacy variables for treatment effects on achievement outcomes. Contemporary Educational Psychology, 11(3), 195-216. https://doi.org/10.1016/0361-476X(86)90017-2

Ried, K., Montgomery, B. D., Stocks, N. P., \& Farmer, E. A. (2008). General practice research training: Impact of the Australian registrar research workshop on research skills, confidence, interest and involvement of participants, 2002-2006. Family Practice, 25(2), 119-126. https://doi.org/10.1093/fampra/cmn010

Rosenblatt, A., \& Kirk, S. A. (1981). Cumulative effect of research courses on knowledge and attitudes of social work students. Journal of Education for Social Work, 17(2), 26-34. https://doi.org/10.1080/00220612.1981.10778548

Rothman, J. (1989). Intervention research: Application to runaway and homeless youths. Social Work Research and Abstracts, 25(1), 13-18. https://doi.org/10.1093/swra/25.1.13

Royal Government of Cambodia. (2019). General population census of the Kingdom of Cambodia 2019. Phnom Penh, Cambodia. Retrieved from https:/cambodia.unfpa.org/en/publications/general-population-census-kingdom-cambodia-20 19

Sachitra, V. (2016). Undergraduates and interest in doing research: Study based on bachelor 
of commerce undergraduates, 4(6), 484-487. https://doi.org/10.12691/education-4-6-7

Sanni, M., Oluwatope, O., Adeyeye, A., \& Egbetokun, A. (2016). Evaluation of the quality of science, technology and innovation advice available to lawmakers in Nigeria. Palgrave Communications, 2. https://doi.org/10.1057/palcomms.2016.95

Seng, C., Carlon, M. K. J., \& Cross, J. S. (2019a). Information literacy training effectiveness on Cambodia's province-based undergraduates. Manuscript submitted for publication.

Seng, C., Carlon, M. K. J., \& Cross, J. S. (2019b). Research self-efficacy of Cambodian undergraduate students at province-based universities. Manuscript submitted for publication.

Sloper, D. W. (Ed.). Higher education in Cambodia: The social and educational context for reconstruction. UNESCO Principal Regional Office for Asia and the Pacific, Bangkok.

The World Bank. (2020). Cambodia and World Bank Join Forces to Improve Higher Education and Connectivity. Retrieved from https://www.worldbank.org/en/news/press-release/2018/07/12/cambodia-and-world-bank-join -forces-to-improve-higher-education-and-connectivity

Tokyo Institute Technology. (2018). Research opportunity in laboratories (TSE). Retrieved from

http://www.ocw.titech.ac.jp/index.php?module=General\&action=T0300\&JWC $=201802721 \&$ lag $=$ EN\&vid $=03$

Turner, N., Wuetherick, B., \& Healey, M. (2008). International perspectives on student awareness, experiences and perceptions of research: Implications for academic developers in implementing research-based teaching and learning. International Journal for Academic Development, 13(3), 199-211. https://doi.org/10.1080/13601440802242333

Un, L., \& Sok, S. (2014). Higher education governance in Cambodia. Leadership and Governance in Higher Education, 4, 72-94. In Leadership and Governance in Higher Education: Handbook for Decision-makers and Administrators, edited by Sjur Bergan, Eva Egron-Polak, Jürgen Kohler and Lewis Purser, 72-94. Berlin: Raabe Academic Publishers.

University World News. (2012). Concern over higher education quality as ASEAN community looms. Retrieved from https://www.universityworldnews.com/post.php?story=20120924142138123

Waldman, M. (2003). Freshmen's use of library electronic resources and self-efficacy. Information Research, 8(2). Retrieved from http://informationr.net/ir/8-2/ paper150.html

Waldrop, M. M. (2013). Campus 2.0: Massive open online courses are transforming higher education and providing fodder for scientific research. Nature News, 495(7440), 160-163. Retrieved from https://www.nature.com/news/online-learning-campus-2-0-1.12590

Webber, K. L., Nelson Laird, T. F., \& BrckaLorenz, A. M. (2013). Student and faculty member engagement in undergraduate research. Research in Higher Education, 54(2), 227-249. https://doi.org/10.1007/s11162-012-9280-5 


\section{Macrothink}

International Journal of Learning and Development

ISSN 2164-4063 2020, Vol. 10, No. 1

Yun, K. (2014). Internationalization of Higher Education in Cambodia: Perceptions, Practices, and Challenges at the Royal University of Phnom Penh (Doctoral dissertation, School of Asia-Pacific Studies, Waseda University). Retrieved from http://hdl.handle.net/2065/39493

\section{Notes}

Note 1. Source: Printed Curriculum for Undergraduate Level of University A (2001), of University B (2007) and of University C (2014).

\section{Copyright Disclaimer}

Copyright for this article is retained by the author(s), with first publication rights granted to the journal.

This is an open-access article distributed under the terms and conditions of the Creative Commons Attribution license (http://creativecommons.org/licenses/by/4.0/). 